\title{
IMMIGRATIE VAN DUITSCHERS IN SURINAME
}

\author{
I733- I 740 \\ DOOR
}

MR. R. BIJLSMA.

Voor den bloei der kolonie Suriname was de vermeerdering der blanke bevolking een zaak van groot gewicht. Om deze vermeerdering te bevorderen, besloten Directeuren der Societeit van Suriname in hunne vergadering van 28 Mei I 727 eene commissie te benoemen tot het beramen van middelen, door welke personen in Europa aangemoedigd zouden worden zich in Suriname te vestigen.

Reeds in de volgende bijeenkomst bracht het lid der commissie Philip Hack de mogelijkheid eener immigratie van Duitschers ter sprake. De uittocht van bewoners der verarmde Paltzstreken naar de Engelsche koloniën in Amerika, die destijds in vollen gang was, leidde een stroom van landverhuizers den Rijn af naar Holland, waar zij zich, voornamelijk te Rotterdam, voor de zeereis inscheepten. Directeur Hack, zelf een Keulenaar van geboorte, vernam bij eene ontmoeting met enkele dezer geëmbarkeerde Paltzers, dat er in hun land ook wel neiging bestond om naar Suriname te trekken. „Paltzers” was de algemeene benaming, waarmede de emigranten uit de Rijnstreken werden aangeduid, en Hack's zegslieden waren dan ook afkomstig uit de graafschap Nassau-Dillenburg. Directeuren der Societeit ontwierpen een plan van voorwaarden, waarop de immigratie zou kunnen geschieden, en zonden dit met de consideratiën van hun mede-lid, den oud-Gouverneur Mr. Paul van der Veen, naar Suriname, om hierover het advies van den Gonverneur in te winnen ${ }^{1}$ ). Toen de papieren in de kolonie arriveerden was Gouverneur Temming juist overleden ; zijn opvolger Carel Henry de Cheusses, die einde I728 het bewind aanvaardde, wachtte met het uitbrengen van zijn

1) Res. Dir. 2 Juli 1727 ; Missivenboek 2 Juli 1727 en 22 Dec. I727. 
advies tot dat hij zich van de koloniale toestanden voldoende op de hoogte had gesteld. Naar zijn oordeel bestond in Suriname groote behoefte aan geschikte plantage-opzichters en ambachtslieden; bij een vestiging der immigranten ergens in de bovenlanden zou het aanleggen van kleine koffieplantages voor hen de meeste kans van welslagen opleveren ${ }^{1}$ ). Na kennisneming van het rapport vereenigden Directeuren zich met eene plaatsing in de bovenlanden en gaven in December I729 aan Philip Hack de opdracht, om met een 5 à 6 -tal Duitsche families over een overtocht te onderhandelen ${ }^{2}$ ).

Hack's bemoeiïngen leidden ertoe, dat in het jaar I733 een paar families uit Altenwied bereid waren naar Suriname te vertrekken; bij de onderhandelingen had de predikant te Altenwied Montanus zijn bemiddeling verleend $\left.{ }^{3}\right)$. De voorwaarden hielden o.a. in als eischen: protestantsche godsdienst, gezond van geste1, mannen niet ouder dan 50 , vrouwen - voor zoover ongehuwd - niet ouder dan 30 jaren; de Societeit verbond zich de transport-kosten te dragen en landbouwgereedschappen ter beschikking te stellen ${ }^{4}$ ).

Twee families, groot I4 personen, met nog 2 ongehuwde mannen arriveerden in October I733 in de kolonie ${ }^{5}$ ). Directeuren der Societeit hadden den Gouverneur opgedragen de immigranten goed te behandelen, opdat nog andere families geanimeerd zouden worden hun geluk in Suriname te beproeven ; over hunne behandeling zou hij te rade kunnen gaan met den predikant Jan Martin Klein, afkomstig uit Neu-Wied, die kort te voren in Suriname was aangekomen $\left.{ }^{6}\right)$.

Gouverneur Carel Henry de Cheusses zou evenwel niets voor de nieuwe kolonisten kunnen doen, daar hij reeds in Januari I734 kwam te overlijden.

Op het einde van het jaar I734 arriveerde een tweede groep immigranten in Suriname; zij bestond uit 4 families uit NeuWied en werd begeleid door den zoon van den Altenwiedschen

1) Brief van 29 Aug. I729.

2) Missivenboek 24 Nov. I729; Res. Dir. I Dec. I729.

3) Res. Dir. 24 April I733.

4) Zie Res. Dir. 6 Dec. I734.

s) Brief Gouverneur 30 Oct. I733.

6) Missivenboek $3 \mathrm{Juli}$ I733. Testament Klein I734 in Notar.-Archief 
pastor, Georg Wilhelm Montanus, die tot predikant in Suriname was aangesteld $\left.{ }^{1}\right)$.

In dezen tijd poogde ook de sekte der Hernhutters in contact te komen met de Societeit van Suriname. Immigratie-voorwaarden werden vastgesteld en in het jaar I735 trokken, zooals bekend is, 3 Hernhutters naar de kolonie, terwij1 in r738 nog een tweede 3 -tal volgde ${ }^{2}$ ).

De kolonisatie met de zoogenaamde Paltzers zou eerst in I739 hervat worden. De Surinaamsche predikant Jan Martin Klein, die wegens kerkelijke geschillen naar Holland was overgekomen, deed in het begin van I738 aan Directeuren der Societeit mededeeling, dat er Paltzische en Neuwiedsche families genegen waren naar Suriname te gaan. Directeuren zonden daarop Klein naar zijn vroegere woonplaats Neu-wied om de onderhandelingen te voeren ${ }^{3}$ ). Deze had zooveel succes met zijn bemoeiïngen, dat Directeuren in Augustus besloten voor den overtocht van $\mathrm{I} 50$ à $\mathrm{I} 60$ immigranten paspoort aan te vragen. De broeder van predikant Klein, te Neu-Wied woonachtig, werd tot correspondent der Societeit voor immigratiezaken aangesteld. Om meerdere bekendheid aan Suriname te geven, ontwierp de secretaris der Societeit eene eenvoudige beschrijving der kolonie, die in Duitsche vertaling voor propaganda gebruikt zou kunnen worden ${ }^{4}$ ).

In Februari I739 arriveerden de immigranten in Suriname; het waren niet minder dan I9 families, die tezamen 96 hoofden telden. Hun komst bracht Gouverneur Van de Schepper in groote verlegenheid, daar hij niet vroeg genoeg gewaarschuwd was, om voor voldoende levensmiddelen enz. te kunnen zorgen. Over het gehalte der kolonisten liet hij zich zeer ongunstig uit ; het was een arm volk, meest vrouwen en met veel kinderen belast ; sommigen hunner waren aan den drank en te lui om hun levensmiddelen-rantsoen aan het fort af te halen. Twee der families verlieten al spoedig Suriname om zich naar de Engelsche kolonie Georgia te begeven.

Daar de Duitschers gekomen waren voor kolonisatie-doel-

1) Res. Dir. 26 Aug. I734.

2) Res. Dir. I en 6 Dec. I734, I2 Sept. I735, 2 Juli I738.

3) Res. Dir. 20 Febr. en 6 Maart I738.

4) Res. Dir. 2 Juli, 6 Aug., 4 Sept. I738; Missivenboek 23 Juni en 6 Aug. I738. 
einden besloot de Gouverneur hen te zenden naar de Patamecakreek aan den bovenloop van de Cottica; een timmerman en 20 slaven gingen mede, om hulp te verleenen bij den houtkap en het gereedmaken van huisvesting ${ }^{1}$ ). De vrouwen en kinderen zouden zoolang zich op een verlaten plantage aldaar ophouden, tot de mannen hooger de rivier op een verblijf hadden gemaakt ${ }^{2}$ )

De kolonisatie liep op een totale mislukking uit. In Juni I739 schreef de Gouverneur naar Amsterdam, dat de Paltzers op ééne familie na alle naar Paramaribo waren teruggekeerd en dat zij weigerden weder naar boven te gaan. Zij beweerden daar alle te zullen sterven en hadden reeds 5 mannen benevens I vrouw en 3 kinderen verloren. In Paramaribo lagen er nog 9 hunner ziek ; die een ambacht verstonden, wilden op eigen hand gaan werken om voor hunne familie den kost te winnen en wenschten niet voor de weduwen en weezen te arbeiden. De vrouwen deden niets dan lamenteeren; sommigen verzochten den Gouverneur naar Nieuw-Engeland te mogen gaan, waar zij konden zaaien en ander boerenwerk verrichten, dat zij geleerd hadden en dat in Suriname niet kon geschieden. De Gouverneur wist niet, wat hij met de ongelukkige weduwen en weezen moest beginnen, daar zij in de kolonie nooit in staat zouden geraken, hun bestaan te verdienen.

In verloop van tijd verergerde de toestand der immigranten in Paramaribo. Blijkens een volgend schrijven van den Gouverneur beliep het aantal dooden reeds 7 mannen, 8 vrouwen en 6 kinderen, terwijl er ook verscheiden zieken waren. Later arriveerden nog een 2-tal Paltzische families uit Europa, waarbij een man, die wegens een zwaren breuk onbekwaam was tot eenigen $\left.\operatorname{arbeid}^{3}\right)$.

In het jaar I740 zou de Gouverneur nog eens gelegenheid hebben, op de Paltzers de aandacht te vestigen. In Suriname waren weder enkele Hernhutters aangekomen, onder wie zich een medicijnmeester bevond, die als hun leider kon optreden. De Hernhutters vingen in Nov. I740 aan te Paramaribo godsdienstoefeningen te houden, waarbij zich ook de Paltzers aansloten. Gouverneur Van de Schepper meende deze sectarische bijeenkomsten niet te mogen gedoogen en wees er den

1) Brieven Gouverneur I4 Febr. en I2 Maart I739.

2) Brief Gouverneur 27 April 1739 .

9) Brieven Gouverneur 20 Juli en 25 Sept. I739. 
Directeuren op, dat de Paltzers een hoop uitschot waren; de vrouwen met haar dochters leidden meest een schandaleus en ongebonden leven, het meerendeel der mannen bestond uit dronkaards en smokkelaars; zij waren lediggangers, die de armoede in Suriname vermeerderden. Wanneer er bij die slechte wereldsche gevoelens bovendien zulke geestelijke bijkwamen, wist de Gouverneur niet, hoe het op 't laatst nog in de kolonie zoude afloopen ${ }^{1}$ ). In hun antwoord droegen de Directeuren der Societeit aan den Gouverneur op, om de bijeenkomsten der Hernhutters in Suriname te verbieden en het verspreiden van gevoelens in strijd met den publieken godsdienst tegen te gaan.

1) Brief Gouverneur I2 Nov. I740. 